\title{
Impacts of nationwide lockdown due to COVID-19 outbreak on air quality in Bangladesh: a spatiotemporal analysis
}

\author{
Md Sariful Islam ${ }^{1}$ (D) $\cdot$ Tanmoy Roy Tusher ${ }^{2,3} \cdot$ Shimul Roy ${ }^{3,4} \cdot$ Mizanur Rahman $^{5}$ \\ Received: 15 July 2020 / Accepted: 2 September 2020 / Published online: 5 September 2020 \\ (C) Springer Nature B.V. 2020
}

\begin{abstract}
In Bangladesh, a nationwide lockdown was imposed on 26 March 2020, due to the COVID-19 pandemic. Due to restricted emissions, it was hypothesized that the air quality has been improved during lockdown throughout the country. The study is intended to assess the impact of nationwide lockdown measures on air quality in Bangladesh. We analyzed satellite data for four different air pollutants $\left(\mathrm{NO}_{2}, \mathrm{SO}_{2}, \mathrm{CO}\right.$, and $\left.\mathrm{O}_{3}\right)$ to assess the changes in the atmospheric concentrations of pollutants in major cities as well as across the country. In this study, the concentrations of $\mathrm{NO}_{2}, \mathrm{SO}_{2}, \mathrm{CO}$, and $\mathrm{O}_{3}$ from 1 February to 30 May of the year 2019 and 2020 were analyzed. The average $\mathrm{SO}_{2}$ and $\mathrm{NO}_{2}$ concentrations were decreased by 43 and $40 \%$, respectively, while tropospheric $\mathrm{O}_{3}$ were found to be increased with a maximum of $>7 \%$. Among the major cities, Dhaka, Gazipur, Chattogram, and Narayanganj were found to be more influenced by the restricted emissions. In Dhaka, $\mathrm{NO}_{2}$ and $\mathrm{SO}_{2}$ concentrations were decreased approximately by 69 and $67 \%$, respectively. Our analysis reveals that $\mathrm{NO}_{2}$ concentrations are highly correlated with the regional COVID-19 cases $(r=0.74)$. The study concludes that the lockdown measures significantly reduced air pollution because of reduced vehicular and industrial emissions in Bangladesh.
\end{abstract}

Keywords COVID-19 $\cdot$ Lockdown $\cdot$ Air pollution $\cdot$ Air quality $\cdot$ Correlation $\cdot$ Bangladesh

\section{Introduction}

The novel coronavirus disease 2019 (COVID-19), is a transmissible disease, caused by the acute respiratory syndrome coronavirus-2 (SARS-CoV-2) (Lu et al. 2020; Sohrabi et al. 2020; Dong et al. 2020). It was first detected in Wuhan City,

Electronic supplementary material The online version of this article (https://doi.org/10.1007/s11869-020-00940-5) contains supplementary material, which is available to authorized users.

Md Sariful Islam

shariful@vt.edu

1 Department of Geography, Virginia Polytechnic Institute and State University, Blacksburg, VA, USA

2 Graduate School of Environmental Studies, Tohoku University, Sendai, Japan

3 Department of Environmental Science and Resource Management, Mawlana Bhashani Science and Technology University,

Tangail, Bangladesh

4 School of Energy and Environment, City University of Hong Kong, Kowloon, Hong Kong, China

5 Department of Geosciences, Florida Atlantic University, Boca Raton, FL, USA
Hubei Province of China on 31 December 2019 (WHO 2020a), which is assumed to be associated with exposures in a local seafood market in Wuhan. This novel coronavirus has become a severe public health issue throughout the world. The World Health Organization (WHO) declared the novel coronavirus disease as a pandemic on 11 March 2020 (WHO 2020b). In 6 months after the first confirmed case in Wuhan, more than 10.6 million people have been infected by COVID19 , and 514,315 people have been reported dead due to the infection in 215 countries, areas, or territories around the world (Worldometer 2020b) (Fig. 1).

Bangladesh, home of $\sim 165$ million people (as of June 2020) with a population density of 1265 people per $\mathrm{km}^{2}$ (Worldometer 2020a), is now struggling with the outbreak of COVID-19. On 8 March 2020, the Institute of Epidemiology, Disease Control and Research (IEDCR) has reported the first three confirmed cases of COVID-19 in Bangladesh (IEDCR 2020). As of 26 June 2020, a total of 126,606 confirmed cases has been reported with 1621 deaths (WHO 2020c). However, among the total number of confirmed cases around the country, only the capital city Dhaka has $\sim 29 \%$ of infected cases (IEDCR 2020).

Air pollution in Bangladesh is a serious concern due to its detrimental impacts. The current air quality index in 


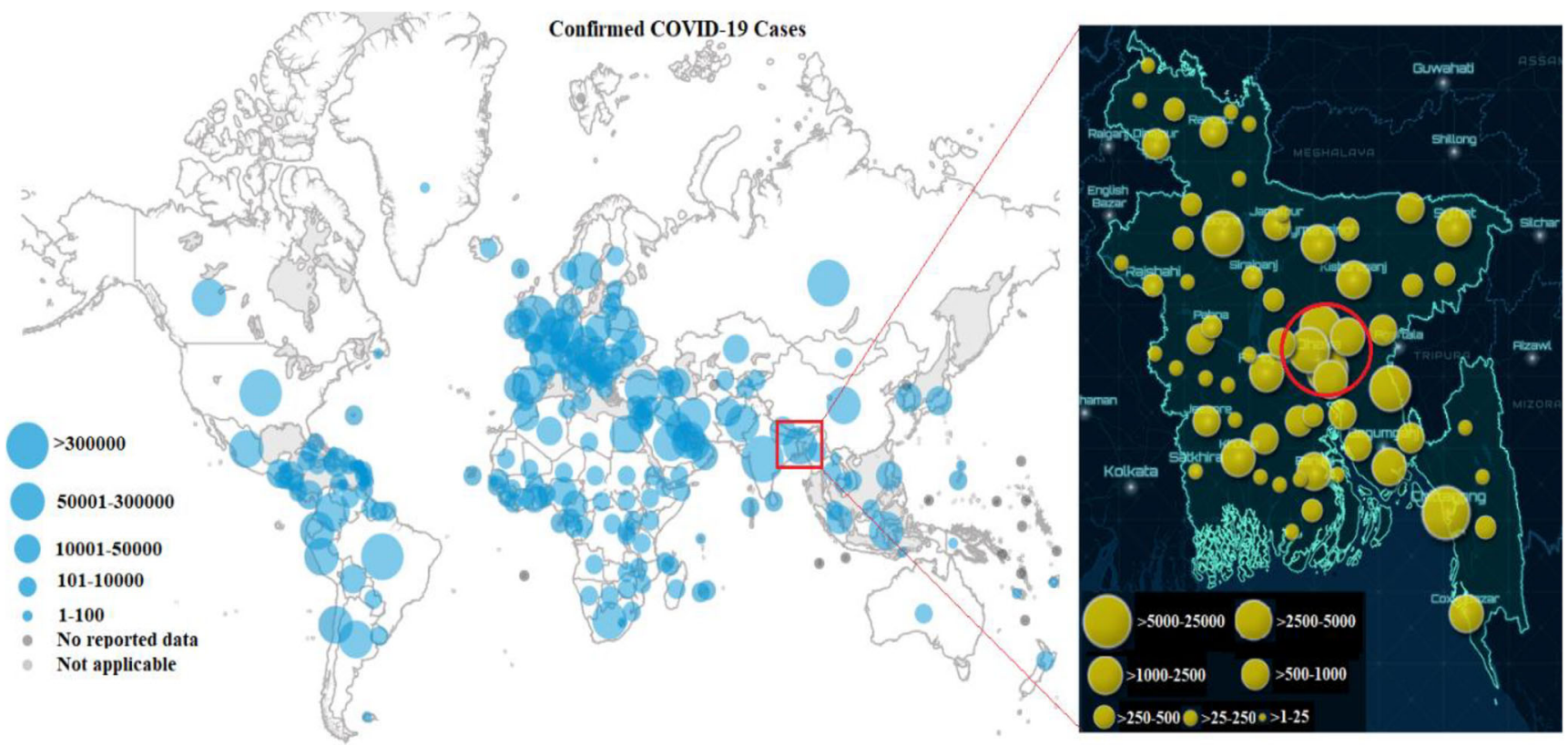

Fig. 1 Distribution of confirmed COVID-19 cases as of 26 June 2020 (WHO 2020c; IEDCR 2020)

Bangladesh is one of the lowest among the countries (rank: 166/180), leading to poor environmental performance index (rank: 162/180) (EPI 2020). Air pollution is strongly associated with respiratory diseases such as asthma, chronic obstructive pulmonary disease (COPD), and lung cancer (Ling and van Eeden 2009; Hoek et al. 2013; Gorai et al. 2016; Guan et al. 2016). Ischemic heart disease and stroke are also caused by air pollution (WHO 2020d). Additionally, it has profound impacts on the transmission of infectious diseases like SARS, influenza, etc. (Cui et al. 2003; Landguth et al. 2020). In Bangladesh, increased air pollution is mainly caused by uncontrolled industrial emissions, vehicle exhausts, and open burning of solid wastes. Every year, a significant number of deaths have been observed due to numerous diseases linked to air pollution (Mahmood 2011).

Like other countries, COVID-19 forced to lock down industries, mass transportation, and other anthropogenic activities in Bangladesh. Hence, it is assumed that the complete or partial lockdown may result in improved air quality, as it is correlated with the amount of emissions. Isaifan (2020) reported a significant drop in $\mathrm{N}_{2} \mathrm{O}$ and carbon emissions (i.e., 30 and $25 \%$, respectively) in China, due to industrial lockdown. Karuppasamy et al. (2020) reported a $55 \%$ reduction in $\mathrm{NO}_{2}$ in India during the lockdown period. Additionally, it is hypothesized that different air pollutants may have a significant relationship with COVID-19 infections, although they are not fully examined, and there remains uncertainty ( $\mathrm{Li}$ et al. 2020). However, some studies (Zhu et al. 2020; Li et al. 2020) reported a considerable relationship between air pollutants and COVID-19 infected cases.

In Bangladesh, some studies (Anwar et al. 2020; Shammi et al. 2020; Islam et al. 2020; Alam et al. 2020) have been conducted to show the socioeconomic impacts of COVID-19 and key challenges to control it and to assess the severity of COVID-19 in the country. However, to the best of our knowledge, there have been no studies on COVID-19 impacts on air quality in Bangladesh. Therefore, this study is conducted to explore the possible impacts of COVID-19 lockdown activities on ambient air quality in Bangladesh as well as to demonstrate the relationships between air pollutants $\left(\mathrm{NO}_{2}, \mathrm{SO}_{2}\right.$, $\mathrm{CO}$, and $\mathrm{O}_{3}$ ) and infected COVID-19 cases.

\section{Status of industrial and vehicular emissions in Bangladesh and associated air quality: literature review}

Economic growth in Bangladesh is one of the fastest growing around the world and largely depends on the country's industrial expansion (Ahaduzzaman et al. 2017). Industrial sector is contributing to more than $35 \%$ of GDP, with an average growth rate of $13 \%$ per year (BER 2019). Almost all of these industries are in major cities of the country, including Dhaka, Narayanganj, Chattogram, Gazipur, Rajshahi, and Khulna (Mahmood 2011; Sabur et al. 2012). Figure S1 depicts the spatial distribution of major industries in Bangladesh. Consequently, these cities comprise a considerable number of motorized vehicles, increasing gradually every year. For instance, in Dhaka, motor vehicle population has increased significantly with a growth rate of $7-16 \%$ in the past 10 years (Begum et al. 2008). Table S1 shows the area and population of major cities of Bangladesh along with the observed air pollutants and number of motor vehicles. As a result, these cities have been experiencing severe air pollution problems 
compared with other parts of the country (Mahmood 2011), while Dhaka is among the most polluted cities in the country and the third most polluted megacities of the world (WHO 2016; Rahman et al. 2019).

In Bangladesh, comprehensive air pollutant emission inventory is still unavailable. Vehicular and industrial emissions are considered the major sources of air pollution in Bangladesh (Mahmood 2011). Alam (2009) reported five industries, including food, cement/clay, pulp and paper, textile, and tobacco, contributed to about $84 \%$ of the country's total industrial air pollution in 2001. Apart from these, brick kilns also cause massive air pollution in the country, particularly in dry season (Mahmood 2011; Guttikunda and Khaliquzzaman 2014; Tusher et al. 2018).

Bangladesh is consistently ranked as one of the most polluted countries in the world for decades. According to the world air quality report (2019) by IQAir, Bangladesh was the most polluted country in 2019. Among the global megacities, Dhaka is consistently ranked as one of the top polluted capital cities. A recent study on air quality in the world's most polluted 50 cities by Rodriguez-Urrego and RodriguezUrrego (2020) found that Dhaka is the second most polluted cities in the world with an average annual $\mathrm{PM}_{2.5}$ level of 97.1 $\mu \mathrm{g} / \mathrm{m}^{3}$. Generally, the level of air pollutants varies with time and seasons. In Dhaka, the average concentrations of major air pollutants except for $\mathrm{O}_{3}$ show strong seasonal variation, with the maximum during winter and minimum during monsoon (Rahman et al. 2019). During the dry season (NovemberApril), the urban areas in Bangladesh suffer from severe air quality problems. During these months, PM concentrations frequently rise to 7-8 times than the WHO standard (Rana and Khan 2020).

\section{Materials and methods}

We collected four different air pollutants' $\left(\mathrm{NO}_{2}, \mathrm{SO}_{2}, \mathrm{CO}\right.$, and $\mathrm{O}_{3}$ ) data for Bangladesh during the period of 1 February to 30 May in 2019 and 2020 using Google Earth Engine (GEE). We acquired daily data from GEE, which is collected by the Sentinel 5 mission of Copernicus ESA with the spatial resolution of 0.01 arc degrees. A detailed summary of the dataset used in this study can be found in Table 1. Statistical data relevant to our study were collected from different secondary sources. District wise confirmed COVID-19 case data (until 26 June 2020) were collected from the Institute of Epidemiology, Disease Control and Research (IEDCR), Bangladesh (https://www.iedcr.gov.bd/). To calculate COVID-19 cases per 100,000 people in Bangladesh, district wise population data have been collected from the Bangladesh Bureau of Statistics (BBS) (http://www.bbs.gov.bd/).

After extracting the daily data on pollutant concentrations, we first classified it into four groups. As our intention was to observe the variation in air quality due to lockdown measures, we divided the data into during lockdown (26 March-30 May 2020), immediate before lockdown (1 February-25 March 2020), same dates during lockdown days in 2019, and same dates of before lockdown in 2019. Hereafter, the daily data of each group were averaged, which are therefore visualized using the ArcMap 10.5.

Summary statistics were calculated for different variables during the lockdown and pre-lockdown periods. We reported both net difference and percentage change of pollutant concentrations during the lockdown and pre-lockdown periods. To have a closer look at the changes in the urban areas, this study also reported change in pollutant concentrations during lockdown vs. pre-lockdown period for 9 major cities in Bangladesh including Sylhet, Rangpur, Rajshahi, Narayanganj, Khulna, Gazipur, Dhaka, Chattogram, and Barisal. A $p<0.05$ was considered statistically significant. Both simple and multiple linear regression analyses were performed to assess the interrelationships between air pollutants and COVID-19 cases. We used district level COVID-19 cases per 100,000 people as dependent variable and air pollutants as independent variable. Pearson's correlation coefficient analysis was employed to analyze the correlation between regional COVID-19 cases and the air pollutants as well as among the air pollutants. The JMP software was used for all statistical analyses in our study.

\section{Results and discussion}

\section{Nitrogen dioxide}

During the lockdown period (i.e., 26 March-30 May 2020) in Bangladesh due to the COVID-19 pandemic, a drastic reduction in $\mathrm{NO}_{2}$ (nitrogen dioxide) concentration has been observed. The significant spatiotemporal changes in $\mathrm{NO}_{2}$ levels (before and during the lockdown) in Bangladesh are shown in Fig. 2. The study revealed that urban areas experienced the most decrease in $\mathrm{NO}_{2}$ concentrations than the rural areas due to restricted traffic and shutdown of industries. This finding is consistent with other previous studies done in different parts of the world (Shi and Brasseur 2020; Sharma et al. 2020; Dantas et al. 2020; Baldasano 2020).

Our study shows that the average decrease in $\mathrm{NO}_{2}$ concentration in all major cities in the country was considerable $(\sim 40 \%)$ during this period (Table 2$)$. However, among the major cities, Narayanganj experienced the highest reduction in $\mathrm{NO}_{2}$ levels (i.e., 69.2\%) compared with the average $\mathrm{NO}_{2}$ concentrations during lockdown with the average concentrations immediately before the lockdown. A similar percentage of $\mathrm{NO}_{2}$ reduction has been observed for Dhaka and Gazipur, ranging from 62 to $69 \%$, while for other cities, it was $\sim 5$ to $38 \%$ 
Table 1 Summary of the datasets used in this study

\begin{tabular}{|c|c|c|c|c|}
\hline Data source & Parameter & $\begin{array}{l}\text { Spatial } \\
\text { resolution }\end{array}$ & $\begin{array}{l}\text { Temporal } \\
\text { resolution }\end{array}$ & Data access link \\
\hline Sentinel 5 & $\begin{array}{l}\text { Tropospheric } \mathrm{NO}_{2} \\
\text { column }\end{array}$ & $\begin{array}{l}0.01 \text { arc } \\
\text { degrees }\end{array}$ & Daily & $\begin{array}{l}\text { https://scihub. } \\
\text { copernicus.eu/ }\end{array}$ \\
\hline Sentinel 5 & $\mathrm{SO}_{2}$ column & $\begin{array}{l}0.01 \text { arc } \\
\text { degrees }\end{array}$ & Daily & $\begin{array}{l}\text { https://scihub. } \\
\text { copernicus.eu/ }\end{array}$ \\
\hline Sentinel 5 & $\mathrm{CO}$ column & $\begin{array}{l}0.01 \text { arc } \\
\text { degrees }\end{array}$ & Daily & $\begin{array}{l}\text { https://scihub. } \\
\text { copernicus.eu/ }\end{array}$ \\
\hline Sentinel 5 & $\mathrm{O}_{3}$ column & $\begin{array}{l}0.01 \text { arc } \\
\text { degrees }\end{array}$ & Daily & $\begin{array}{l}\text { https://scihub. } \\
\text { copernicus.eu/ }\end{array}$ \\
\hline $\begin{array}{l}\text { IEDCR, } \\
\text { Bangladesh }\end{array}$ & $\begin{array}{l}\text { COVID-19 cases in } \\
\text { BD }\end{array}$ & - & - & $\begin{array}{l}\text { https://www.iedcr.gov. } \\
\text { bd// }\end{array}$ \\
\hline $\begin{array}{l}\text { BBS, } \\
\text { Bangladesh }\end{array}$ & Population data & - & 2011 & http://www.bbs.gov.bd/ \\
\hline
\end{tabular}

(Table 2). Note that emission of $\mathrm{NO}_{2}$ is strongly related to the fuel combustion in the industrial sector (e.g., power plants and small-scale heating sources) and in road transport (e.g., gasoline-powered vehicles). Therefore, it is
Fig. 2 Spatiotemporal distribution of average $\mathrm{NO}_{2}$ over Bangladesh: (a) 1 February-25 March 2019, (b) 26 March-30 May 2019, (c) 1 February-25 March 2020, and (d) 26 March30 May 2020

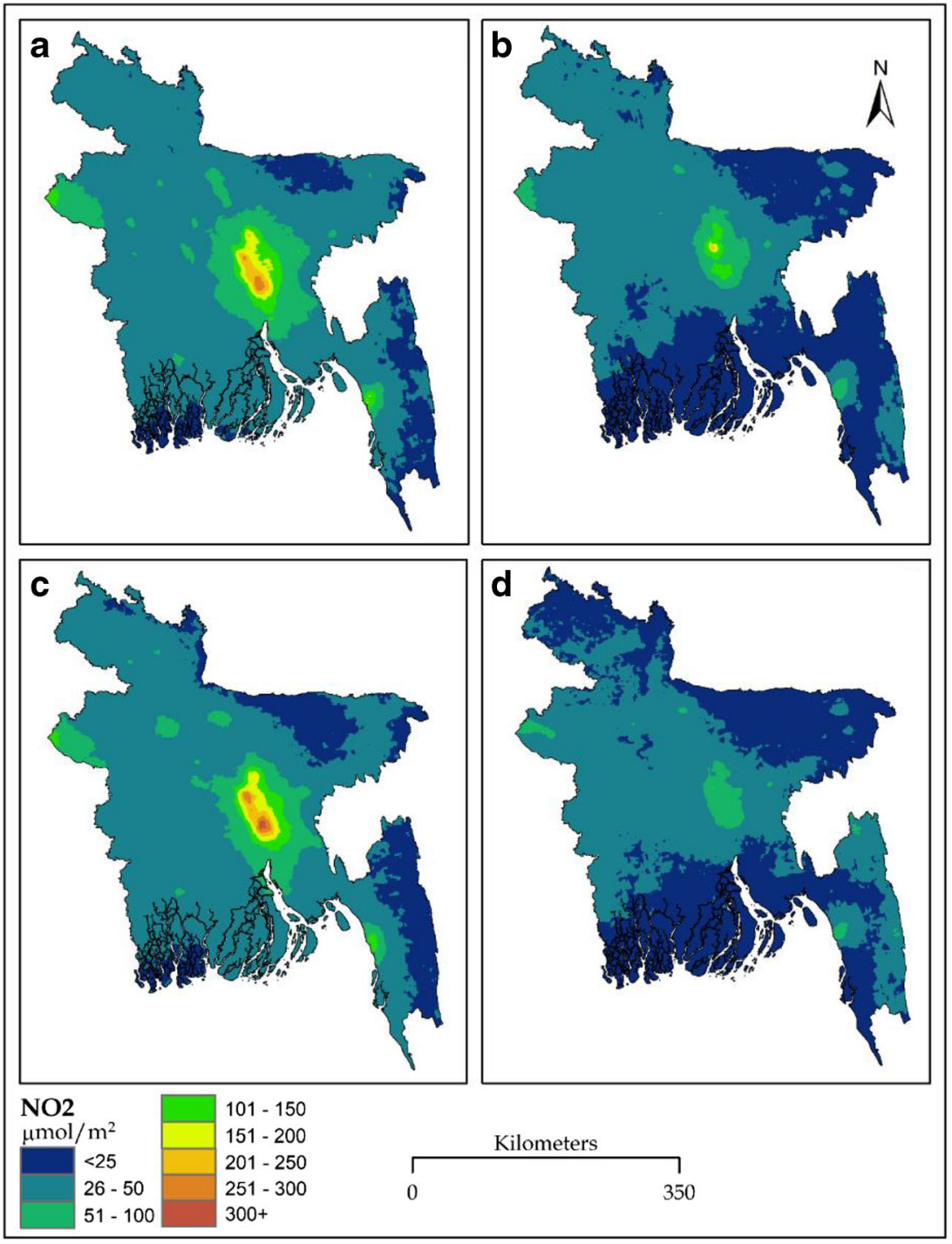


Table 2 Mean concentrations and variations of $\mathrm{NO}_{2}$ at major cities in Bangladesh before and during lockdown

\begin{tabular}{|c|c|c|c|c|c|c|c|}
\hline \multirow[t]{2}{*}{ City } & \multicolumn{5}{|c|}{$\mathrm{NO}_{2}\left(\mu \mathrm{mol} / \mathrm{m}^{2}\right)$} & \multicolumn{2}{|l|}{ Variation* } \\
\hline & $2019^{a}$ & $2019^{b}$ & $2020^{\mathrm{a} 1}$ & Average $\mathrm{A}^{\#}$ & $2020^{\mathrm{b} 1}$ & Net & Percent $(\%)$ \\
\hline Sylhet & 46.12 & 30.84 & 40.5 & 39.15 & 31 & -9.5 & -23.46 \\
\hline Rangpur & 32.68 & 28.51 & 35.56 & 32.25 & 33.87 & -1.69 & -4.75 \\
\hline Rajshahi & 58.53 & 43.32 & 54.1 & 51.98 & 42.92 & -11.18 & -20.67 \\
\hline Narayanganj & 248.44 & 95.61 & 278.32 & 207.46 & 85.62 & -192.7 & -69.24 \\
\hline Khulna & 49.23 & 34.02 & 46.84 & 43.36 & 30.24 & -16.6 & -35.44 \\
\hline Gazipur & 189.31 & 153.3 & 225.41 & 189.34 & 83.76 & -141.65 & -62.84 \\
\hline Dhaka & 212.51 & 103.6 & 221.9 & 179.35 & 68.73 & -153.17 & -69.03 \\
\hline Chattogram & 115.09 & 71.78 & 90.3 & 92.39 & 58.57 & -31.73 & -35.14 \\
\hline Barisal & 39.61 & 25.84 & 39.3 & 34.92 & 24.34 & -14.96 & -38.07 \\
\hline
\end{tabular}

${ }^{\text {a }}$ Average of daily concentration from 1 February to 25 March; ${ }^{\text {a1 }} \mathrm{NO}_{2}$ concentration before the lockdown;

${ }^{\mathrm{b}}$ average of daily concentration from 26 March to $30 \mathrm{May}$; ${ }^{\mathrm{b} 1} \mathrm{NO}_{2}$ concentration during the lockdown; *variation before and during the COVID-19 lockdown period; " average concentration of 2019a, 2019b, and 2020a expected that these sectoral activities' restrictions result in a significant reduction in $\mathrm{NO}_{2}$ concentration during the lockdown period.

Compared with the average $\mathrm{NO}_{2}$ values before lockdown, Dhaka was found to be experienced with the highest $\mathrm{NO}_{2}$ reduction (62\%). Surprisingly, $\sim 5 \%$ increase in $\mathrm{NO}_{2}$ concentration has been observed for Rangpur. We assume that the long-range transport from northern India could be the potential reason behind this increasing $\mathrm{NO}_{2}$. However, while comparing the $2019 \mathrm{NO}_{2}$ concentrations with the same time slot in 2020 (i.e., during the lockdown period), significant $\mathrm{NO}_{2}$ reduction is observed for most of the major cities except Rangpur. The highest decline was in Gazipur (45\%), followed by Dhaka (34\%) and Chattogram (18\%), as presented in Table 2.

These results are consistent with the findings of the previously published works. Baldasano (2020) reported similar findings for Madrid (Spain) during the lockdown compared with the same period in 2019. In Delhi (India), $\mathrm{NO}_{2}$ concentrations were reduced by approximately $53 \%$ during the lockdown period compared with the same period in 2019 (Mahato et al. 2020). Agarwal et al. (2020) reported an average $\mathrm{NO}_{2}$ reduction of $\sim 49 \%$ and $>76 \%$ during the lockdown in China and Mumbai (India), respectively. In summary, this reduction in $\mathrm{NO}_{2}$ concentrations in different time slots indicates that lockdown measures due to the COVID-19 pandemic have considerable impacts on changing $\mathrm{NO}_{2}$ concentrations in Bangladesh.

\section{Sulfur dioxide}

Considerable reduction in $\mathrm{SO}_{2}$ (sulfur dioxide) concentrations has also been observed owing to the nationwide lockdown as presented in Fig. 3. The study revealed that $\mathrm{SO}_{2}$ concentrations during this period are relatively lower than the 2019 levels for the same time frame (Fig. 3). It indicates the reduced $\mathrm{SO}_{2}$ emissions due to the shutdown of industrial processes, power plants, and heating systems. A similar pattern of $\mathrm{SO}_{2}$ reduction has been reported in China (Wang et al. 2020; Bao and Zhang 2020; Li et al. 2020), Italy (Collivignarelli et al. 2020), and India (Mahato et al. 2020). Moreover, lower $\mathrm{SO}_{2}$ concentrations are usually found in Bangladesh during the end of March to May 2019, compared with the early January to end of March 2019 (Fig. 3), which might be attributed to the increased rainfall during these months (Shahid 2010).

Besides, we observed notable findings when making the analysis and inter-comparing among the nine major cities of the country. The study found that all the studied cities experienced a substantial reduction in $\mathrm{SO}_{2}$ concentrations, except Rangpur (Table 3). Among the nine cities, Chattogram experienced a maximum decrease in $\mathrm{SO}_{2}$ levels (i.e., 69.15\%) during the lockdown period compared with the concentrations observed immediately before the lockdown. However, a considerable reduction has also been observed in Dhaka, Narayanganj, Khulna, Rajshahi, and Gazipur, which ranged from 40.5 to $66.6 \%$ (Table 3 ), as industrial zones are mostly concentrated in these cities (Sabur et al. 2012). Therefore, the highest reduction in the $\mathrm{SO}_{2}$ concentrations is reasonable due to the stoppage of all industrial activities and limited vehicle movements. A similar result has been observed in New Delhi (India) and Milan (Italy) where about 18 and $25.4 \%$ reduction in $\mathrm{SO}_{2}$ concentrations were reported, respectively, during partial/total lockdown period in comparison with the prelockdown period (Mahato et al. 2020; Collivignarelli et al. 2020). Comparatively, a lower reduction in $\mathrm{SO}_{2}$ has been observed in other cities. We assume that uncontrolled or partial controlled industrial and vehicular activities could be the inherent reason in this regard.

Interestingly, we observe a slight increase in $\mathrm{SO}_{2}$ concentrations in Rangpur (Table 3), which might be attributed to the 
Fig. 3 Spatiotemporal distribution of average $\mathrm{SO}_{2}$ over Bangladesh: (a) 1 February-25 March 2019, (b) 26 March-30 May 2019, (c) 1 February-25

March 2020, and (d) 26 March30 May 2020
Table 3 Mean concentrations and variations of $\mathrm{SO}_{2}$ at major cities in Bangladesh before and during lockdown

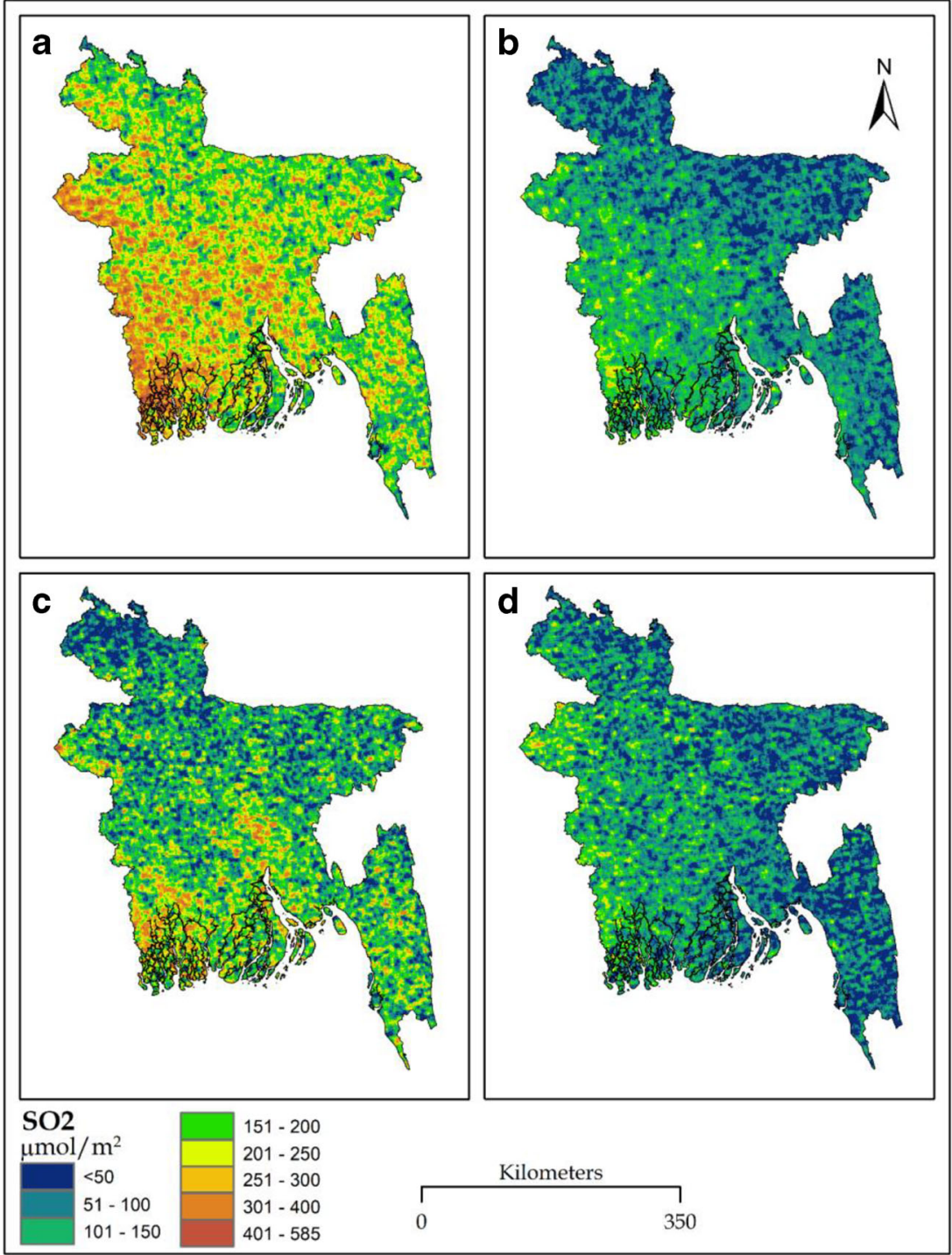

\begin{tabular}{|c|c|c|c|c|c|c|c|}
\hline \multirow[t]{2}{*}{ City } & \multicolumn{5}{|c|}{$\mathrm{SO}_{2}\left(\mu \mathrm{mol} / \mathrm{m}^{2}\right)$} & \multicolumn{2}{|c|}{ Variation* } \\
\hline & $2019^{a}$ & $2019^{\mathrm{b}}$ & $2020^{\mathrm{a} 1}$ & Average ${ }^{\#}$ & $2020^{\mathrm{b} 1}$ & Net & Percent $(\%)$ \\
\hline Sylhet & 129.77 & 75.94 & 86.94 & 97.55 & 69.57 & -17.37 & -19.98 \\
\hline Rangpur & 180.18 & 53.82 & 140.25 & 124.75 & 147.2 & 6.95 & 4.96 \\
\hline Rajshahi & 300.71 & 133.01 & 231.35 & 221.69 & 101.91 & -129.44 & -55.95 \\
\hline Narayanganj & 265.98 & 100.68 & 330.78 & 232.48 & 118.94 & -211.84 & -64.04 \\
\hline Khulna & 261.36 & 115.78 & 286.72 & 221.29 & 109.63 & -177.09 & -61.76 \\
\hline Gazipur & 265.14 & 137.05 & 218.42 & 206.87 & 129.97 & -88.45 & -40.50 \\
\hline Dhaka & 299.71 & 124.44 & 262.4 & 228.85 & 87.61 & -174.79 & -66.61 \\
\hline Chattogram & 204.68 & 119.76 & 209.61 & 178.02 & 64.67 & -144.94 & -69.15 \\
\hline Barisal & 175.31 & 113.56 & 150.13 & 146.33 & 131.89 & -18.24 & -12.15 \\
\hline
\end{tabular}

${ }^{\text {a }}$ Average of daily concentration from 1 February to 25 March; ${ }^{\text {al }} \mathrm{SO}_{2}$ concentration before the lockdown; ${ }^{\mathrm{b}}$ average of daily concentration from $26 \mathrm{March}$ to $30 \mathrm{May} ;{ }^{\mathrm{b} 1} \mathrm{SO}_{2}$ concentration during the lockdown; *variation before and during the COVID-19 lockdown period; " average concentration of 2019a, 2019b, and 2020a 
transboundary $\mathrm{SO}_{2}$ emission sources. For example, Sharma et al. (2020) observed a slight increase in $\mathrm{SO}_{2}$ concentrations when studying the changes in air pollutants' levels during the lockdown in 22 Indian cities. They correlated such an increase in $\mathrm{SO}_{2}$ concentration to the resultant emissions originating from power plants in the northern India, where no restriction was enforced.

\section{Carbon monoxide}

Like $\mathrm{NO}_{2}$, a substantial reduction in $\mathrm{CO}$ (carbon monoxide) concentration was observed, as presented in Fig. 4. Even the average concentration of $\mathrm{CO}$ during the lockdown period was less than the average $\mathrm{CO}$ values in 2019 for the same period. The study shows that urban areas experienced a substantial reduction in $\mathrm{CO}$ concentration compared with rural areas, mainly due to restricted traffic movement and the shutdown of industrial activities. As high emission of $\mathrm{CO}$ is the result of the incomplete fuel combustion (i.e., incomplete oxidation of hydrocarbons), mainly from the automobiles (Miller 2011; Reşitoğlu et al. 2015), therefore, a significant reduction in $\mathrm{CO}$ due to limited vehicle movement is reasonable. The spatiotemporal changes in $\mathrm{CO}$ concentrations in Bangladesh for the selected time slots are presented in Fig. 4.

Table 4 shows a noticeable decrease in $\mathrm{CO}$ concentrations in all major cities in Bangladesh during the lockdown period compared with before lockdown, ranging from 1.6 to $>7 \%$. The highest reduction in $\mathrm{CO}$ has been observed in Narayanganj, as it is the major industrial zone with heavy congestion of commercial transportation (gasoline and diesel-powered), and other public and private vehicles. However, a considerable emission reduction has also been observed in other industrial cities (i.e., Dhaka, Gazipur, and Chattogram), where the average reduction was $5.3 \%$ (Table 4). Similarly, while the CO concentrations during the lockdown in 2020 were compared with 2019 emission levels
Fig. 4 Spatiotemporal distribution of average $\mathrm{CO}$ over Bangladesh: (a) 1 February-25 March 2019, (b) 26 March-30 May 2019, (c) 1 February-25 March 2020, and (d) 26 March30 May 2020

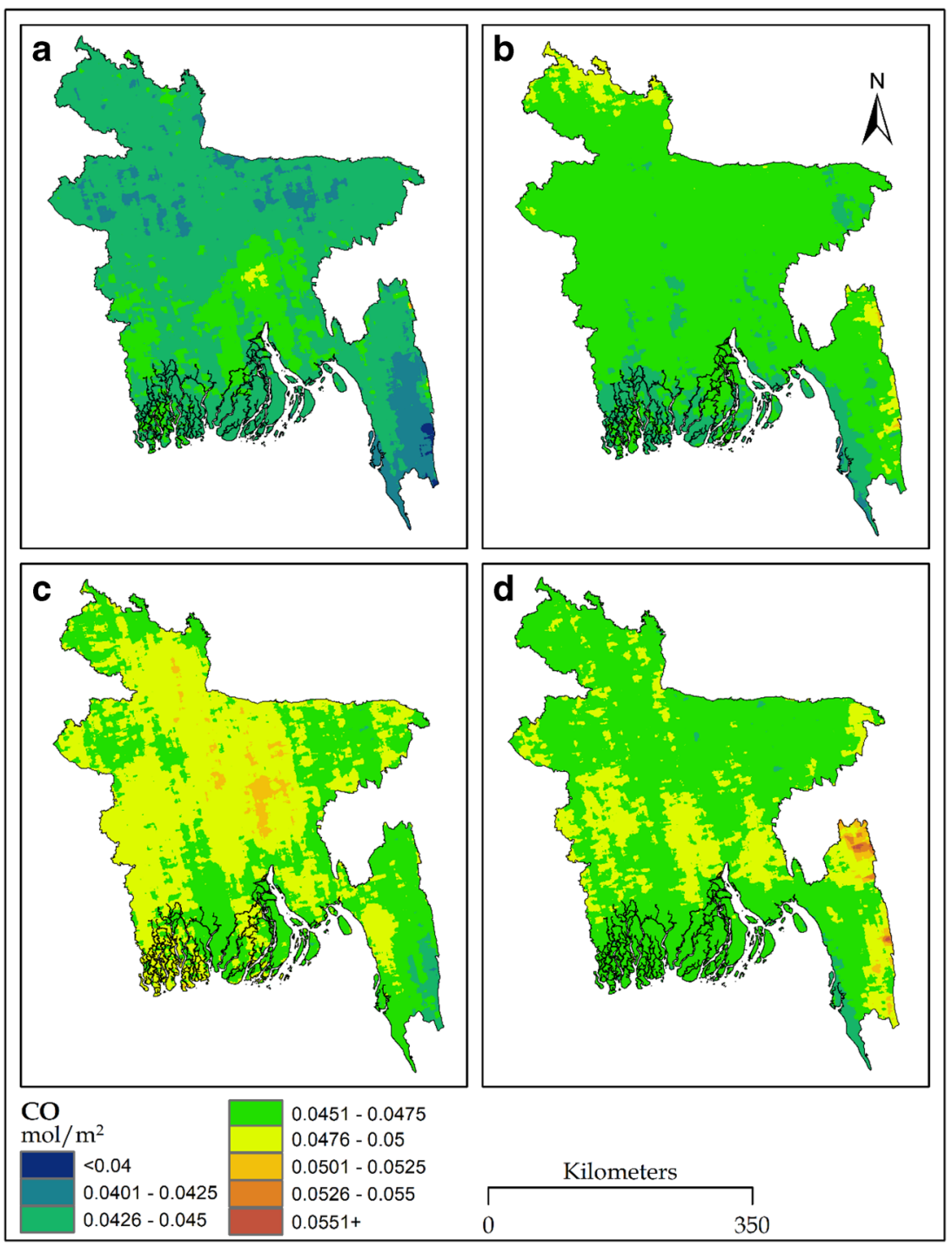


Table 4 Mean concentrations and variations of $\mathrm{CO}$ at major cities in Bangladesh before and during lockdown

\begin{tabular}{|c|c|c|c|c|c|c|c|}
\hline \multirow[t]{2}{*}{ City } & \multicolumn{5}{|c|}{$\mathrm{CO}\left(\mathrm{mol} / \mathrm{m}^{2}\right)$} & \multicolumn{2}{|c|}{ Variation* } \\
\hline & $2019^{\mathrm{a}}$ & $2019^{b}$ & $2020^{\mathrm{a} 1}$ & Average ${ }^{\#}$ & $2020^{\mathrm{b} 1}$ & Net & Percent $(\%)$ \\
\hline Sylhet & 0.0437 & 0.0456 & 0.0476 & 0.0456 & 0.0467 & -0.0009 & -1.89 \\
\hline Rangpur & 0.0440 & 0.0473 & 0.0488 & 0.0467 & 0.0474 & -0.0014 & -2.87 \\
\hline Rajshahi & 0.0436 & 0.0465 & 0.0477 & 0.0459 & 0.0469 & -0.0009 & -1.68 \\
\hline Narayanganj & 0.0468 & 0.0458 & 0.0502 & 0.0476 & 0.0466 & -0.0036 & -7.17 \\
\hline Khulna & 0.0448 & 0.0453 & 0.0480 & 0.0460 & 0.0472 & -0.0007 & -1.67 \\
\hline Gazipur & 0.0469 & 0.0467 & 0.0500 & 0.0479 & 0.0474 & -0.0026 & -5.20 \\
\hline Dhaka & 0.0476 & 0.0461 & 0.0496 & 0.0478 & 0.0468 & -0.0029 & -5.65 \\
\hline Chattogram & 0.0435 & 0.0437 & 0.0477 & 0.0450 & 0.0453 & -0.0024 & -5.03 \\
\hline Barisal & 0.0453 & 0.0461 & 0.0481 & 0.0465 & 0.0471 & -0.0009 & -2.08 \\
\hline
\end{tabular}

${ }^{a}$ Average of daily concentration from 1 February to $25 \mathrm{March} ;{ }^{\text {al }} \mathrm{CO}$ concentration before the lockdown; ${ }^{\mathrm{b}}$ average of daily concentration from 26 March to $30 \mathrm{May} ;{ }^{\mathrm{b} 1} \mathrm{CO}$ concentration during the lockdown; *variation before and during the COVID-19 lockdown period; " average concentration of 2019a, 2019b, and 2020a for the same period, relatively lower $\mathrm{CO}$ concentration was found during the lockdown period. These results are consistent with the findings reported for Madrid (Spain) and Delhi (India) during the lockdown period (Mahato et al. 2020; Baldasano 2020).

\section{Ozone}

Like other pollutants, partial or complete lockdown measure also has a noticeable impact on $\mathrm{O}_{3}$ (ozone) concentration, as presented in Fig. 5. Our study reveals that $\mathrm{O}_{3}$ concentration in Bangladesh has increased during the lockdown period. A similar observation has been reported for Spain and Italy during the lockdown period in 2020 (Tobías et al. 2020; Coccia 2020)

Table 5 shows an increased $\mathrm{O}_{3}$ concentration during the lockdown in all major cities in Bangladesh, with a percentage increase of 1.26 to $5 \%$. Among all major cities, Chattogram experienced a maximum increase in $\mathrm{O}_{3}$ concentration compared with the levels observed immediately before the lockdown (i.e., 271.95 vs. 285.75 DU), as shown in Table 5. A similar pattern of variation in $\mathrm{O}_{3}$ concentration is found for other major cities with an average change of $281.37 \mathrm{vs} .288 .59$ DU before and during the lockdown. Even the $\mathrm{O}_{3}$ concentration was also found higher in all major cities during the lockdown period in 2020 compared with the 2019 levels for the same period. This increase in $\mathrm{O}_{3}$ concentration is possibly due to the significant reduction in $\mathrm{NO}_{2}$ concentration, which leads to more photochemical activity in the atmosphere, resulting in more $\mathrm{O}_{3}$ production (Dang and Liao 2019; Li et al. 2019).

Interestingly, a slight decrease in $\mathrm{O}_{3}$ concentration has been found in Rangpur during the lockdown period compared with before the lockdown (i.e., 294.12 vs. 293.56 DU) (Table 5). This study assumes some reasons behind the decreasing $\mathrm{O}_{3}$ levels in Rangpur. First, it might be due to the lack of proper implementation of lockdown measures in Rangpur, and second, emissions from the northern India might have considerable impacts on the reducing $\mathrm{O}_{3}$ concentration in Rangpur, as the emissions of $\mathrm{NO}$ from industries and vehicles diminish the level of $\mathrm{O}_{3}$ (titration, $\mathrm{NO}+\mathrm{O}_{3}=\mathrm{NO}_{2}+\mathrm{O}_{2}$ ). Overall, this study assumes that restricted anthropogenic activities lead to an increase in $\mathrm{O}_{3}$ concentration during the lockdown period in Bangladesh.

\section{Relationship between COVID-19 cases and air pollutants}

The associations between daily air pollutants' concentrations and COVID-19 confirmed cases (from 8 March to 26 June 2020) as well as the correlations among the studied air pollutants are presented in Figs. 6 and 7 and Table 6. In Fig. 6, the linear regression analysis indicated that infection by COVID-19 was greatly influenced by the atmospheric concentrations of each air pollutants, while positive associations were observed with $\mathrm{NO}_{2}\left(R^{2}=0.55\right), \mathrm{SO}_{2}\left(R^{2}=0.14\right)$, and $\mathrm{CO}$ $\left(R^{2}=0.07\right)$, and negative association was found with $\mathrm{O}_{3}\left(R^{2}=\right.$ 0.09). These results exhibited strong association between $\mathrm{NO}_{2}$, as a single predictor, with COVID-19 cases per 100,000 persons (Fig. 6). On the other hand, the multiple linear regression model observed that all the studied air pollutants, except CO, were significantly associated with the COVID-19 cases in Bangladesh $\left(R^{2}=0.65\right)$ (Table 6). Similarly, Pearson's correlation matrix also showed significant interrelations among air pollutants and between COVID-19 confirmed cases with daily mean concentrations of air pollutants (Fig. 7). Significantly positive correlations were observed among $\mathrm{NO}_{2}-\mathrm{CO}(r=0.56 * * * *), \mathrm{NO}_{2}-\mathrm{SO}_{2}(r$ $=0.44 * * *), \mathrm{NO}_{2}-\mathrm{COVID}-19$ cases $(r=0.74 * * * *), \mathrm{SO}_{2}-$ COVID-19 cases $\left(r=0.38^{* *}\right), \mathrm{CO}^{-} \mathrm{O}_{3}(r=0.30 *)$, and $\mathrm{CO}-$ COVID-19 cases $\left(r=0.27^{*}\right)$, whereas significantly negative 
Fig. 5 Spatiotemporal distribution of average $\mathrm{O}_{3}$ over Bangladesh: (a) 1 February-25 March 2019, (b) 26 March-30 May 2019, (c) 1 February-25

March 2020, and (d) 26 March30 May 2020
Table 5 Mean concentrations and variations of $\mathrm{O}_{3}$ at major cities in Bangladesh before and during lockdown
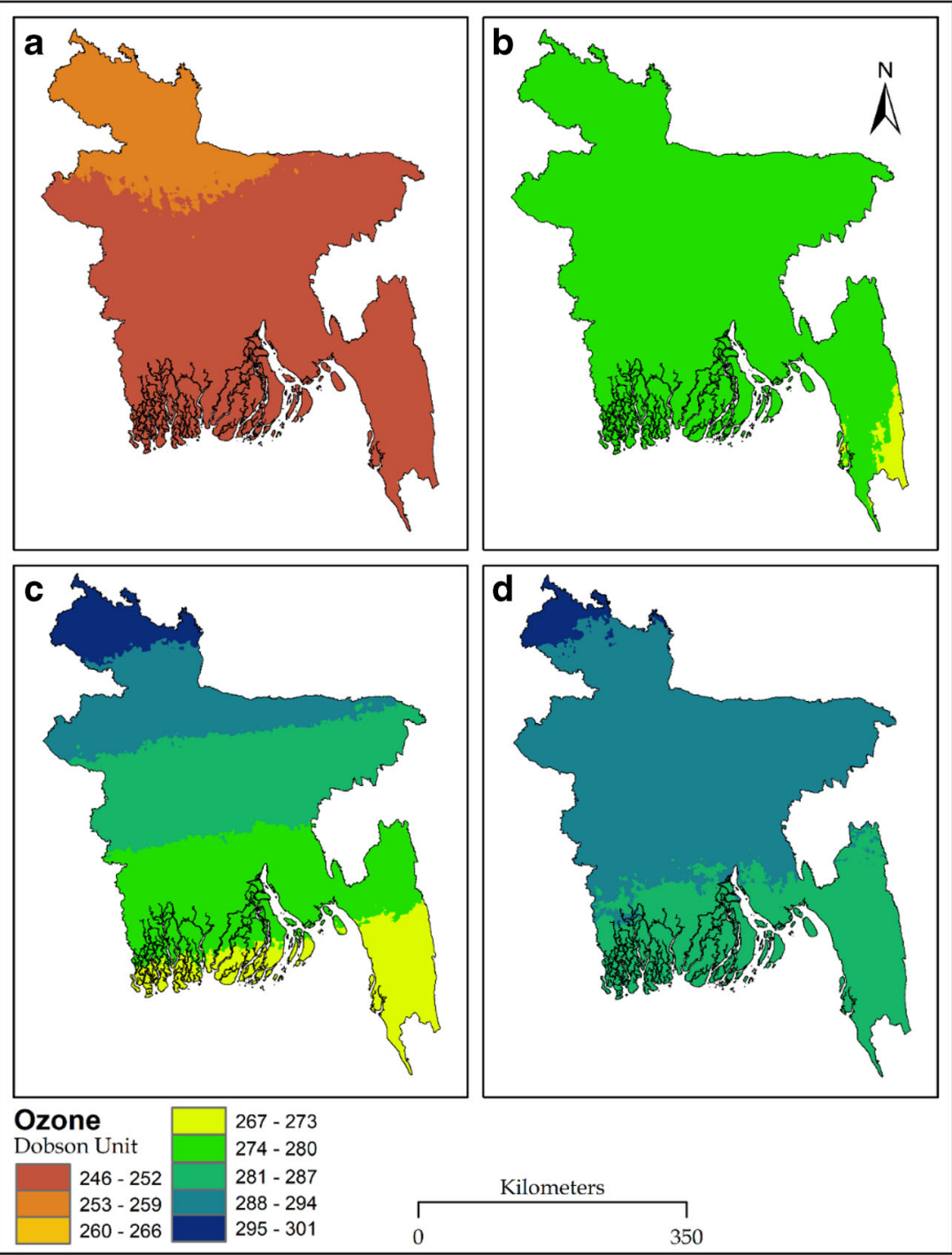

\begin{tabular}{|c|c|c|c|c|c|c|c|}
\hline \multirow[t]{2}{*}{ City } & \multicolumn{5}{|c|}{$\mathrm{O}_{3}$ (Dobson unit) } & \multicolumn{2}{|c|}{ Variation* } \\
\hline & $2019^{a}$ & $2019^{\mathrm{b}}$ & $2020^{\mathrm{a} 1}$ & Average $^{\#}$ & $2020^{\mathrm{b} 1}$ & Net & Percent $(\%)$ \\
\hline Sylhet & 251.04 & 275.34 & 286.18 & 270.85 & 290.61 & 4.43 & 1.55 \\
\hline Rangpur & 254.35 & 278.64 & 294.12 & 275.70 & 293.56 & -0.56 & -0.19 \\
\hline Rajshahi & 251.24 & 277.05 & 286.76 & 271.68 & 290.37 & 3.61 & 1.26 \\
\hline Narayanganj & 250.47 & 275.84 & 279.56 & 268.62 & 287.86 & 8.3 & 2.97 \\
\hline Khulna & 250.22 & 275.27 & 276.65 & 267.38 & 286.6 & 9.95 & 3.60 \\
\hline Gazipur & 250.83 & 275.73 & 281.16 & 269.24 & 288.53 & 7.37 & 2.62 \\
\hline Dhaka & 250.66 & 275.9 & 280.76 & 269.11 & 288.18 & 7.42 & 2.64 \\
\hline Chattogram & 249.07 & 274.61 & 271.95 & 265.21 & 285.75 & 13.8 & 5.07 \\
\hline Barisal & 250.23 & 274.8 & 275.2 & 266.74 & 285.85 & 10.65 & 3.87 \\
\hline
\end{tabular}

${ }^{\mathrm{a}}$ Average of daily concentration from 1 February to $25 \mathrm{March} ;{ }^{\mathrm{a} 1} \mathrm{O}_{3}$ concentration before the lockdown; ${ }^{\mathrm{b}}$ average of daily concentration from 26 March to $30 \mathrm{May} ;{ }^{\mathrm{b} 1} \mathrm{O}_{3}$ concentration during the lockdown; *variation before and during the COVID-19 lockdown period; ${ }^{*}$ average concentration of 2019a, 2019b, and 2020a 
Table 6 Multiple regression model results for the relation between air pollutants and COVID-19 cases

\begin{tabular}{llllll}
\hline Term & Estimate & t Ratio & Lower 95\% & Upper 95\% & Prob $>|t|$ \\
\hline Intercept & 794.65091 & 3.61 & 353.65572 & 1235.6461 & $0.0006^{*}$ \\
Carbon monoxide $(\mathrm{CO})$ & -4338.958 & -1.05 & -12637.74 & 3959.8276 & 0.2997 \\
Nitrogen dioxide $\left(\mathrm{NO}_{2}\right)$ & 0.9633442 & 8.25 & 0.7296115 & 1.1970768 & $<0.0001^{*}$ \\
Ozone $\left(\mathrm{O}_{3}\right)$ & -1.990334 & -3.28 & -3.205185 & -0.775483 & $0.0018^{*}$ \\
Sulfur dioxide $\left(\mathrm{SO}_{2}\right)$ & -0.243428 & -2.33 & -0.452871 & -0.033985 & $0.0235^{*}$ \\
\hline
\end{tabular}

$R^{2}=0.65, R M S E=21.05$ correlations were found among $\mathrm{O}_{3}-\mathrm{SO}_{2}(r=-0.71 * * * *)$ and $\mathrm{O}_{3}$-COVID-19 cases $\left(r=-0.30^{*}\right)$ (Fig. 7). However, statistically non-significant positive and negative relations were observed among $\mathrm{SO}_{2}-\mathrm{CO}(r=0.03)$ and $\mathrm{O}_{3}-\mathrm{NO}_{2}(r=-0.09)$, respectively. The higher correlation coefficient value with positive association among two air pollutants possibly exhibited mutual dependence and common pollution sources (e.g., industrial and vehicular emissions).

Our findings are found to be in line with the results of other studies conducted in other COVID-19-affected cities or regions (Martelletti and Martelletti 2020; Ogen 2020; Zhu et al. 2020; Fattorini and Regoli 2020), which clearly exhibited that atmospheric concentration of air pollutants is an important risk factor for COVID-19. It can, therefore, be stated that cities with higher concentrations of air pollutants are at high risk of COVID-19 infection. However, we could not include PM pollution in our analysis owing to data unavailability, which is one of the major air pollutants and has the potential to influence COVID-19 causality. In addition, the correlations among air pollutants imply that reduction in the atmospheric concentrations of air pollutants was the resultant effect of the enforcement of lockdown in anthropogenic activities. Several other studies (Sharma et al. 2020; Dantas et al. 2020; Kerimray et al. 2020; Mahato et al. 2020; Bao and Zhang 2020) also observed the similar types of interrelationship and reported the decreased concentrations of atmospheric $\mathrm{NO}_{2}, \mathrm{SO}_{2}$, and $\mathrm{CO}$, while the concentration of $\mathrm{O}_{3}$ was increased, resulting in improved air quality in the studied cities and/or the country.
Fig. 6 Linear regression analysis of regional COVID-19 cases and daily air pollutants' concentrations in Bangladesh: number of COVID-19 cases per 100,000 people vs. daily mean levels of $\mathrm{NO}_{2}$ (a), $\mathrm{SO}_{2}$ (b), $\mathrm{CO}$ (c), and $\mathrm{O}_{3}$ (d)
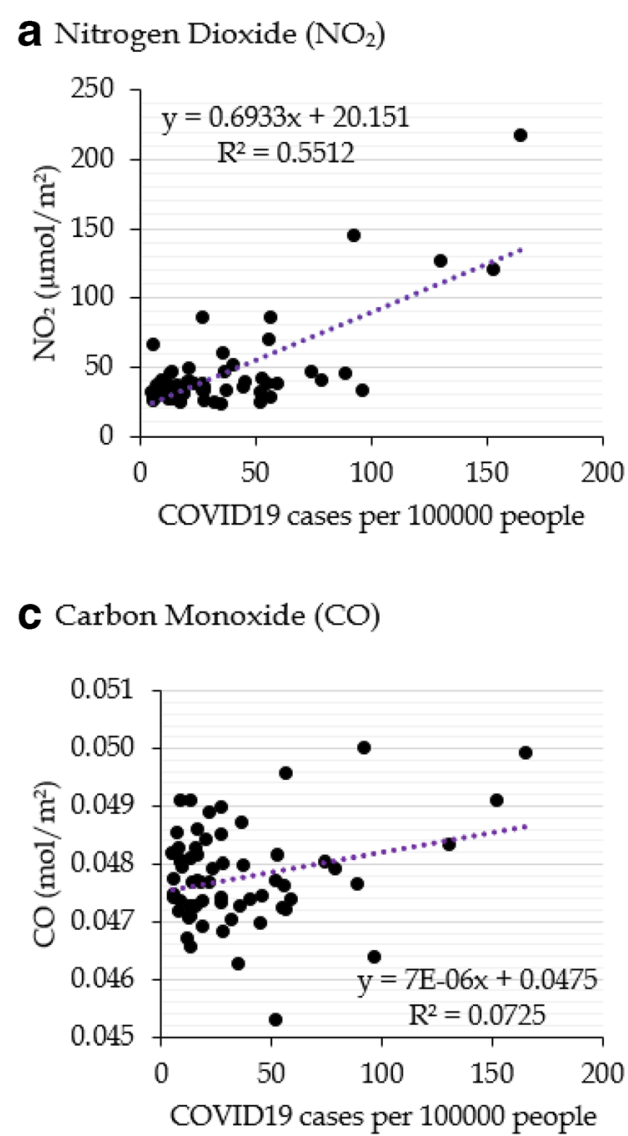

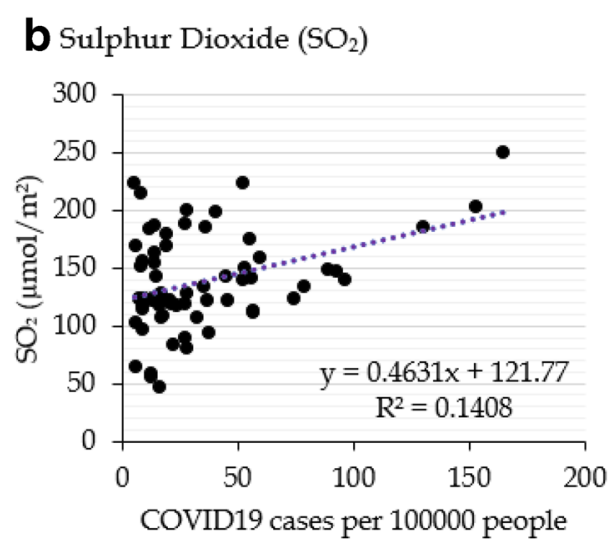

d Ozone $\left(\mathrm{O}_{3}\right)$

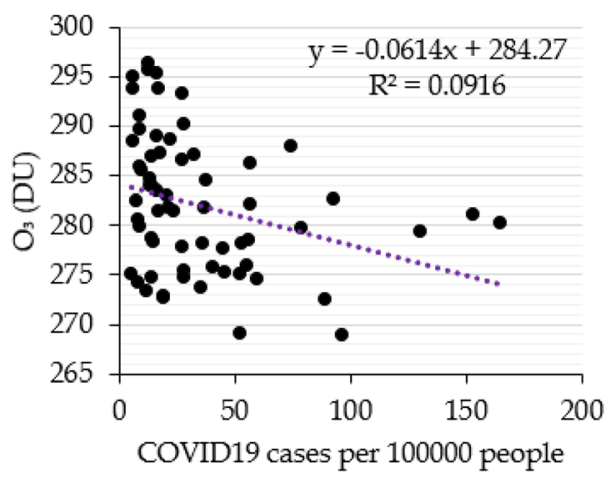


Fig. 7 Scatterplot matrix of Pearson's correlation among air pollutants and between air pollutants' concentrations and COVID-19 confirmed cases. ****indicates $P<0.0001, * * *$ in dicates $P<0.001$, **indicates $P<$ 0.01 , and $*$ indicates $P<0.05$; the scale bar represents the correlation coefficient value $(r)$

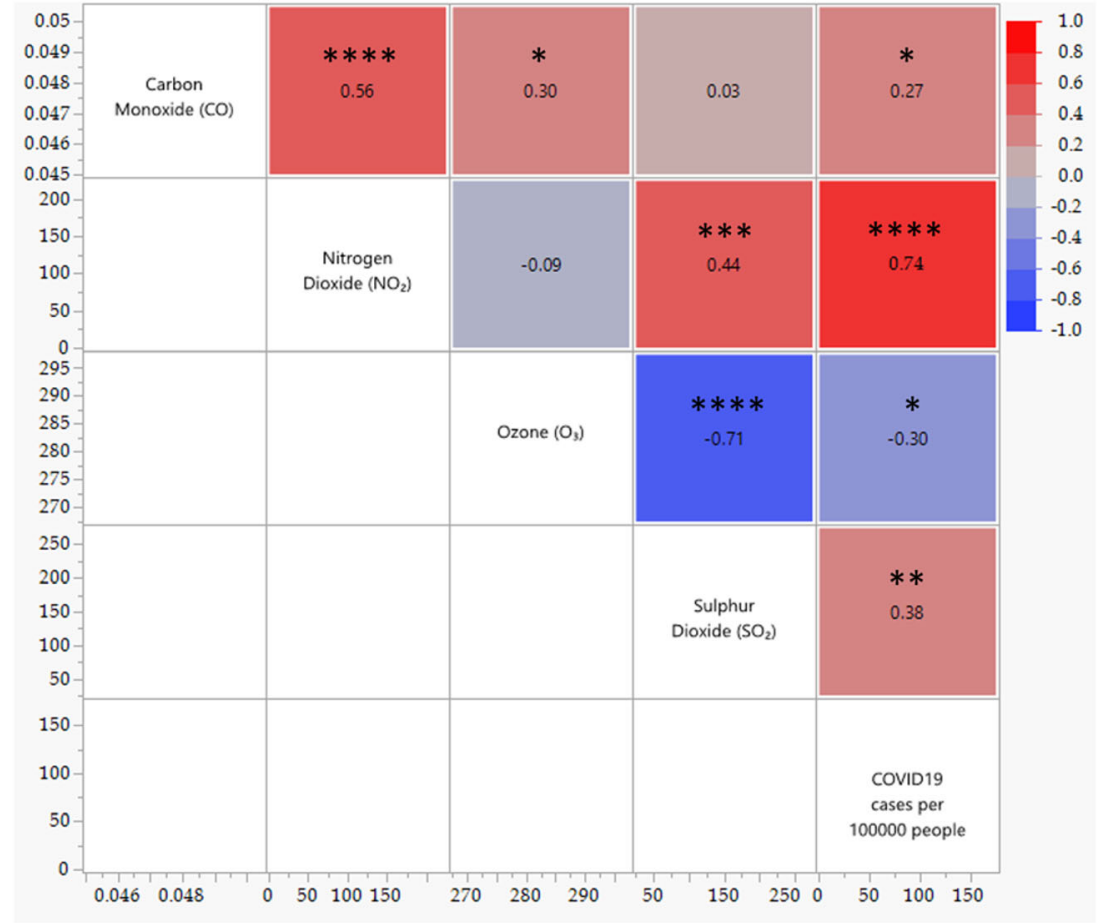

\section{Conclusion}

The effects of lockdown in anthropogenic activities due to the COVID-19 pandemic on air quality in Bangladesh were studied by analyzing the concentrations of air pollutants and analyzing the spatial distribution changes. Satellite data of different pollutants during 2019-2020 were used to illustrate how restricted anthropogenic activities during COVID-19 lockdown reduced air pollution in Bangladesh. The study revealed that among all pollutants, the highest average reduction was in $\mathrm{SO}_{2}$ (i.e., $\sim 43 \%$ ) followed by $\mathrm{NO}_{2}$ and $\mathrm{CO}$ during the lockdown period. On the contrary, an average increase of $\sim 3 \%$ was observed for $\mathrm{O}_{3}$, which we believe was due to the significant reduction in $\mathrm{NO}_{2}$ concentration during the lockdown period. The study shows that major industrial cities experienced a significant reduction in pollutant concentrations compared with less urbanized cities. The study also identified that $\mathrm{NO}_{2}$ is highly correlated with the number of COVID-19 confirmed cases.

In most developing countries, including Bangladesh, updated emission data and air quality data are not available due to limited resources, lack of comprehensive emission inventory, and lack of proper planning and policy concerning pollution control. Satellite observations are a tremendous resource for studying air quality over large geographic regions, mainly for most developing countries like Bangladesh. We believe that our study has provided a baseline scenario that will eventually help the concerned authorities for future air quality management in Bangladesh through policy reforms, mainly on industrial and vehicular emission restrictions. Moreover, it will provide the input data for regional air quality simulation. However, in our study, we did not consider the influence of meteorological conditions on air quality. As the country has distinct seasonal variations due to its geographic location, therefore, we believe meteorological parameters have a considerable influence on air quality during the pre-lockdown and lockdown period. Further study is recommended considering the impacts of meteorological conditions on air quality in Bangladesh.

Acknowledgments The authors are thankful to all the anonymous reviewers for their valuable comments and suggestions to further improve the manuscript. The authors are also grateful to the European Earth Observation Programme "Copernicus" of the European Commission (EC) for providing the access to the Sentinel-5 satellite data.

Funding This research did not receive any funding.

Data availability Not applicable.

\section{Compliance with ethical standards}

Conflict of interest The authors declare that they have no conflict of interest.

Code availability Not applicable.

\section{References}

Agarwal A, Kaushik A, Kumar S, Mishra RK (2020) Comparative study on air quality status in Indian and Chinese cities before and during 
the COVID-19 lockdown period. Air Qual Atmos Health. https:// doi.org/10.1007/s11869-020-00881-z

Ahaduzzaman, Sarkar P, Anjum A, Khan EA (2017) Overview of major industries in Bangladesh. J Chem Eng 30:51-58. https://doi.org/10. 3329/jce.v30i1.34798

Alam GMJ (2009) Environmental pollution of Bangladesh - its effect and control. In: International conference (ICME 2009), 26-28 December, Dhaka

Alam MS, Alam MZ, Nazir KNH, Bhuiyan MAB (2020) The emergence of novel coronavirus disease (COVID-19) in Bangladesh: present status, challenges, and future management. J Adv Vet Anim Res 7: 198-208

Anwar S, Nasrullah M, Hosen MJ (2020) COVID-19 and Bangladesh: challenges and how to address them. Front Public Health 8. https:// doi.org/10.3389/fpubh.2020.00154

Baldasano JM (2020) COVID-19 lockdown effects on air quality by NO2 in the cities of Barcelona and Madrid (Spain). Sci Total Environ 741:140353. https://doi.org/10.1016/j.scitotenv.2020.140353

Bao R, Zhang A (2020) Does lockdown reduce air pollution? Evidence from 44 cities in northern China. Sci Total Environ 731:139052. https://doi.org/10.1016/j.scitotenv.2020.139052

Begum BA, Biswas SK, Hopke PK (2008) Assessment of trends and present ambient concentrations of PM2.2 and PM10 in Dhaka, Bangladesh. Air Qual Atmos Health 1:125-133. https://doi.org/10. 1007/s11869-008-0018-7

BER (2019) GDP, savings and investment (Chapter 2). Bangladesh Economic Review (BER) 2019, Ministry of Finance. Government of the People's Republic of Bangladesh, Bangladesh, $\mathrm{p} 19$

Coccia M (2020) Factors determining the diffusion of COVID-19 and suggested strategy to prevent future accelerated viral infectivity similar to COVID. Sci Total Environ 729:138474. https://doi.org/10. 1016/j.scitotenv.2020.138474

Collivignarelli MC, Abbà A, Bertanza G, Pedrazzani R, Ricciardi P, Carnevale Miino M (2020) Lockdown for CoViD-2019 in Milan: what are the effects on air quality? Sci Total Environ 732:139280. https://doi.org/10.1016/j.scitotenv.2020.139280

Cui Y, Zhang Z-F, Froines J, Zhao J, Wang H, Yu SZ, Detels R (2003) Air pollution and case fatality of SARS in the People's Republic of China: an ecologic study. Environ Health 2:15. https://doi.org/10. 1186/1476-069X-2-15

Dang R, Liao H (2019) Radiative forcing and health impact of aerosols and ozone in China as the consequence of clean air actions over 2012-2017. Geophys Res Lett 46:12511-12519. https://doi.org/ 10.1029/2019GL084605

Dantas G, Siciliano B, França BB, da Silva CM, Arbilla G (2020) The impact of COVID-19 partial lockdown on the air quality of the city of Rio de Janeiro, Brazil. Sci Total Environ 729:139085. https://doi. org/10.1016/j.scitotenv.2020.139085

Dong E, Du H, Gardner L (2020) An interactive web-based dashboard to track COVID-19 in real time. Lancet Infect Dis 20:533-534. https:// doi.org/10.1016/S1473-3099(20)30120-1

EPI (2020) 2020 Environmental Performance Index. Yale Center for Environmental Law \& Policy, New Haven https://epi.yale.edu/epiresults/2020/component/air. Accessed 13 Jun 2020

Fattorini D, Regoli F (2020) Role of the chronic air pollution levels in the Covid-19 outbreak risk in Italy. Environ Pollut 264:114732. https:// doi.org/10.1016/j.envpol.2020.114732

Gorai AK, Tchounwou PB, Tuluri F (2016) Association between ambient air pollution and asthma prevalence in different population groups residing in Eastern Texas, USA. Int J Environ Res Public Health 13: 378. https://doi.org/10.3390/ijerph13040378

Guan W-J, Zheng X-Y, Chung KF, Zhong N-S (2016) Impact of air pollution on the burden of chronic respiratory diseases in China: time for urgent action. The Lancet 388:1939-1951. https://doi.org/ 10.1016/S0140-6736(16)31597-5
Guttikunda SK, Khaliquzzaman M (2014) Health benefits of adapting cleaner brick manufacturing technologies in Dhaka, Bangladesh. Air Qual Atmos Health 7:103-112. https://doi.org/10.1007/ s11869-013-0213-z

Hoek G, Krishnan RM, Beelen R, Peters A, Ostro B, Brunekreef B, Kaufman JD (2013) Long-term air pollution exposure and cardiorespiratory mortality: a review. Environ Health 12:43. https://doi. org/10.1186/1476-069X-12-43

IEDCR (2020) Bangladesh Covid-19 update. https://www.iedcr.gov.bd/. Accessed 27 Jun 2020

Isaifan RJ (2020) The dramatic impact of coronavirus outbreak on air quality: has it saved as much as it has killed so far? Glob J Environ Sci Manag 6:275-288. https://doi.org/10.22034/gjesm. 2020.03.01

Islam MS, Ira JI, Kabir KMA, Kamrujjaman M (2020) Effect of lockdown and isolation to suppress the COVID-19 in Bangladesh: an epidemic compartments model. https://doi.org/10.20944/ preprints202004.0193.v2

Karuppasamy MB, Seshachalam S, Natesan U, Ayyamperumal R, Karuppannan S, Gopalakrishnan G, Nazir N (2020) Air pollution improvement and mortality rate during COVID-19 pandemic in India: global intersectional study. Air Qual Atmos Health. https:// doi.org/10.1007/s11869-020-00892-w

Kerimray A, Baimatova N, Ibragimova OP, Bukenov B, Kenessov B, Plotitsyn P, Karaca F (2020) Assessing air quality changes in large cities during COVID-19 lockdowns: the impacts of traffic-free urban conditions in Almaty, Kazakhstan. Sci Total Environ 730: 139179. https://doi.org/10.1016/j.scitotenv.2020.139179

Landguth EL, Holden ZA, Graham J, Stark B, Mokhtari EB, Kaleczyc E, Anderson S, Urbanski S, Jolly M, Semmens EO, Warren DA, Swanson A, Stone E, Noonan C (2020) The delayed effect of wildfire season particulate matter on subsequent influenza season in a mountain west region of the USA. Environ Int 139:105668. https:// doi.org/10.1016/j.envint.2020.105668

Li K, Jacob DJ, Liao H, Shen L, Zhang Q, Bates KH (2019) Anthropogenic drivers of 2013-2017 trends in summer surface ozone in China. Proc Natl Acad Sci U S A 116:422-427. https:// doi.org/10.1073/pnas.1812168116

Li L, Li Q, Huang L, Wang Q, Zhu A, Xu J, Liu Z, Li H, Shi L, Li R, Azari M, Wang Y, Zhang X, Liu Z, Zhu Y, Zhang K, Xue S, Ooi MCG, Zhang D, Chan A (2020) Air quality changes during the COVID-19 lockdown over the Yangtze River Delta region: an insight into the impact of human activity pattern changes on air pollution variation. Sci Total Environ 732:139282. https://doi.org/10. 1016/j.scitotenv.2020.139282

Li H, Xu X-L, Dai D-W, Huang ZY, Ma Z, Guan YJ (2020) Air pollution and temperature are associated with increased COVID-19 incidence: a time series study. Int J Infect Dis 97:278-282. https://doi.org/10. 1016/j.ijid.2020.05.076

Ling SH, van Eeden SF (2009) Particulate matter air pollution exposure: role in the development and exacerbation of chronic obstructive pulmonary disease. Int J Chron Obstruct Pulmon Dis 4:233-243

Lu R, Zhao X, Li J, Niu P, Yang B, Wu H, Wang W, Song H, Huang B, Zhu N, Bi Y, Ma X, Zhan F, Wang L, Hu T, Zhou H, Hu Z, Zhou W, Zhao L, Chen J, Meng Y, Wang J, Lin Y, Yuan J, Xie Z, Ma J, Liu WJ, Wang D, Xu W, Holmes EC, Gao GF, Wu G, Chen W, Shi W, Tan W (2020) Genomic characterisation and epidemiology of 2019 novel coronavirus: implications for virus origins and receptor binding. The Lancet 395:565-574. https://doi.org/10.1016/S01406736(20)30251-8

Mahato S, Pal S, Ghosh KG (2020) Effect of lockdown amid COVID-19 pandemic on air quality of the megacity Delhi, India. Sci Total Environ 730:139086. https://doi.org/10.1016/j.scitotenv.2020. 139086

Mahmood SAI (2011) Air pollution kills 15,000 Bangladeshis each year: the role of public administration and governments integrity. J Public 
Adm Policy Res 3:129-140. https://doi.org/10.5897/JPAPR. 9000004

Martelletti L, Martelletti P (2020) Air pollution and the novel Covid-19 disease: a putative disease risk factor. Sn Compr Clin Med 2:1-5. https://doi.org/10.1007/s42399-020-00274-4

Miller BG (2011) 4 - The effect of coal usage on human health and the environment. In: Miller BG (ed) Clean Coal Engineering Technology. Butterworth-Heinemann, Boston, pp 85-132

Ogen Y (2020) Assessing nitrogen dioxide (NO2) levels as a contributing factor to coronavirus (COVID-19) fatality. Sci Total Environ 726: 138605. https://doi.org/10.1016/j.scitotenv.2020.138605

Rahman MM, Mahamud S, Thurston GD (2019) Recent spatial gradients and time trends in Dhaka, Bangladesh, air pollution and their human health implications. J Air Waste Manag Assoc 69:478-501. https:// doi.org/10.1080/10962247.2018.1548388

Rana MM, Khan MH (2020) Trend characteristics of atmospheric particulate matters in major urban areas of Bangladesh. Asian J Atmos Environ 14:47-61. https://doi.org/10.5572/ajae.2020.14.1.047

Reșitoğlu İA, Altinișik K, Keskin A (2015) The pollutant emissions from diesel-engine vehicles and exhaust aftertreatment systems. Clean Technol Environ Policy 17:15-27. https://doi.org/10.1007/s10098014-0793-9

Rodríguez-Urrego D, Rodríguez-Urrego L (2020) Air quality during the COVID-19: PM2.5 analysis in the 50 most polluted capital cities in the world. Environ Pollut 266:115042. https://doi.org/10.1016/j. envpol.2020.115042

Sabur MA, Khan AA, Safiullah S (2012) Treatment of textile wastewater by coagulation precipitation method. J Sci Res 4:623-633. https:// doi.org/10.3329/jsr.v4i3.10777

Shahid S (2010) Rainfall variability and the trends of wet and dry periods in Bangladesh. Int J Climatol 30:2299-2313. https://doi.org/10. 1002/joc. 2053

Shammi M, Bodrud-Doza M, Towfiqul Islam ARM, Rahman MM (2020) COVID-19 pandemic, socioeconomic crisis and human stress in resource-limited settings: a case from Bangladesh. Heliyon 6:e04063. https://doi.org/10.1016/j.heliyon.2020.e04063

Sharma S, Zhang M, Anshika et al (2020) Effect of restricted emissions during COVID-19 on air quality in India. Sci Total Environ 728: 138878. https://doi.org/10.1016/j.scitotenv.2020.138878

Shi X, Brasseur GP (2020) The response in air quality to the reduction of Chinese economic activities during the COVID-19 outbreak. Geophys Res Lett 47:e2020GL088070. https://doi.org/10.1029/ 2020GL088070

Sohrabi C, Alsafi Z, O'Neill N et al (2020) World Health Organization declares global emergency: a review of the 2019 novel coronavirus
(COVID-19). Int J Surg 76:71-76. https://doi.org/10.1016/j.jjsu. 2020.02.034

Tobías A, Carnerero C, Reche C, Massagué J, Via M, Minguillón MC, Alastuey A, Querol X (2020) Changes in air quality during the lockdown in Barcelona (Spain) one month into the SARS-CoV-2 epidemic. Sci Total Environ 726:138540. https://doi.org/10.1016/j. scitotenv.2020.138540

Tusher TR, Akter S, Ashraf Z et al (2018) Phytomonitoring of brick kiln induced air pollution at Konabari of Bangladesh. Malays J Sci 37: 50-69. https://doi.org/10.22452/mjs.vol37,no1.4

Wang P, Chen K, Zhu S, Wang P, Zhang H (2020) Severe air pollution events not avoided by reduced anthropogenic activities during COVID-19 outbreak. Resour Conserv Recycl 158:104814. https:// doi.org/10.1016/j.resconrec.2020.104814

WHO (2016) WHO global urban ambient air pollution database (update 2016). Available at: https://www.who.int/airpollution/data/cities2016/en/. Accessed 17 Aug 2020

WHO (2020a) Coronavirus Disease 2019 (COVID-19): Situation Report-1. World Health Organization, Geneva https://www.who. int/docs/default-source/coronaviruse/situation-reports/20200121sitrep-1-2019-ncov.pdf?sfvrsn=20a99c10 4. Accessed 11 Jun 2020

WHO (2020b) Coronavirus Disease 2019 (COVID-19): Situation Report-51. World Health Organization, Genev Available at: https://www.who.int/docs/default-source/coronaviruse/situationreports/20200311-sitrep-51-covid-19.pdf? Accessed 11 Jun 2020

WHO (2020c) WHO coronavirus disease (COVID-19) dashboard. Available at: https://covid19.who.int/. Accessed 11 Jun 2020

WHO (2020d) Mortality and burden of disease from ambient air pollution. Available at: https://www.who.int/gho/phe/outdoor_air_ pollution/burden_text/en/. Accessed 13 Jun 2020

Worldometer (2020a) Annual population data of Bangladesh. Available at: https://www.worldometers.info/world-population/bangladeshpopulation/. Accessed 11 Jun 2020

Worldometer (2020b) COVID-19 coronavirus pandemic. Available at: https://www.worldometers.info/coronavirus/. Accessed 27 Jun 2020

Zhu Y, Xie J, Huang F, Cao L (2020) Association between short-term exposure to air pollution and COVID-19 infection: evidence from China. Sci Total Environ 727:138704. https://doi.org/10.1016/j. scitotenv.2020.138704

Publisher's note Springer Nature remains neutral with regard to jurisdictional claims in published maps and institutional affiliations. 